УДК 140.8:784+159.9.01

\author{
Іван Васильович Бобул, \\ завідувач кафедри естрадного співу \\ Київської муніципальної академії \\ естрадного та циркового мистецтва \\ Konuschenko65@gmail.com
}

\title{
ПРОВІДНІ ТЕНДЕНЦІЇ ЖАНРОВОЇ СТРАТИФІКАЦІЇ УКРАЇНСЬКОГО ВОКАЛЬНО-ЕСТРАДНОГО ВИКОНАВСТВА
}

Мета роботи постає як визначення тих тенденцій жанрової стратифікації українського вокально-естрадного виконавства, що вказують на його власну системну художню організацію. Методологія дослідження зумовлена поєднанням гносеологічного мистецтвознавчого та текстологічного музикознавчого підходів на основі культурологічного дискурсу. Наукова новизна роботи полягає у виявленні чотирьох провідних тенденцій розвитку вокально-естрадної жанрової системи, що надають ій художньо-творчої та культурно-семантичної автономії - театралізації, фестивалізації, академізації та персоналізації. Висновки. Вокально-естрадне виконавство в Україні є найбільш широкою та об'ємною за жанровими складовими сферою музично-сценічної творчості, що має власну систему гносеологічних та аксіологічних ознак, виводить сучасне і актуальне на рівень універсальних категорій - скерована до ідеї всезагального глобалізованого соціуму, надаючи ціннісного темпорального виміру повсякденній свідомості, веде до нової академізації, тому базується на принципах професійної композиторської й виконавської творчості та здійснюе стильові і стилістичні інновації. Підпорядковуючи ліричну, індивідуально-особистісну образну сферу, надає їй особливої художньоігрової концептуалізації.

Ключові слова: украӥнське вокально-естрадне виконавство, жанрова стратифікація, театралізація, фестивалізація, академізація, персоналізація, художньо-ігрова концептуалізація.

Bobul Ivan Vasilyevich, head of the Department of Variety Singing Kyiv Municipal Academy variety and circus art

Leading tendencies of genre stratification of Ukrainian vocal-pop performances

The purpose of the work is to identify the tendencies of the genre stratification of Ukrainian vocal-pop performances, which point to its own systemic artistic organization. The methodology of the study is determined by a combination of epistemological art and textual musicology approaches based on cultural discourse. The scientific novelty of the work is identifying the four leading trends in the development of the vocal-pop genre system, which provide it with artis-

(C) Бобул I. В., 2016 
tic-creative and cultural-semantic autonomy - theatricalization, festivaling, academicization and personalization. Conclusions. Vocal-pop performance in Ukraine is the most extensive and voluminous genre component of the field of musical and stage creativity, which has its own system of epistemological and axiological features, deduces contemporary and relevant to the level of universal categories - geared towards the idea of an all-globalized society, providing value temporal measurement of everyday consciousness leads to a new academic formation, therefore, it is based on the principles of professional composer and performing arts and carries style and stylistic innovations. Subordinating to the lyrical, individual-personal imaginary sphere, it gives it a special artistic-game conceptualization.

Keywords: Ukrainian vocal-pop performance, genre stratification, theatricalization, festivaling, academy, personalization, artistic-game conceptualization.

И. Бобул, заведуюший кафедрой эстрадного пения Киевской муниципальной академии эстрадного и циркового искусства

Ведущие тенденции жанровой стратификации украинского вокально-эстрадного исполнительства

Целью работы выступает определение тех тенденций жанровой стратификации украинского вокально-эстрадного исполнительства, которые указывают на его собственную системную художественную организацию. Методология исследования обусловлена сочетанием гносеологического искусствоведческого и текстологического музыковедческого подходов на основе культурологического дискурса. Научная новизна работы заключается в выявлении четырех ведущих тенденций развития вокально-эстрадной жанровой системы, обеспечивающих ее художественно-творческую и культурно-семантическую автономию - театрализации, фестивализации, академизации и персонализации. Выводы. Вокально-эстрадное исполнительство в Украине является наиболее широкой и объемной по жканровым составляющим сферой музыкальносценического творчества, имеющей собственную систему гносеологических и аксиологических признаков, выводит современное и актуальное на уровень универсальных категорий - направлена к идее всеобщего глобализирующегося социума, наделяя ценностным темпоральным измерением обыденное сознание, ведет к новой академизации, поэтому базируется на принципах профессионального композиторского и исполнительского творчества и осуществляет стилевые и стилистические инновации. Подчиняя лирическую, индивидуально-личностную образную сферу, сообщает ей особую художественно-игровую концептуализацию.

Ключевые слова: украинское вокально-эстрадное исполнительство, жанровая стратификация, театрализация, фестивализация, академизация, персонализация, художественно-игровая концептуализация. 
Актуальність теми дослідження. Незважаючи на істотні відмінності жанрових проекцій українського вокально-естрадного виконавства, вони виявляють спільність комунікативних якостей, вірніше, єдність художньо-комунікативного походження, шо свідчить про їх історичний та структурно-семантичний зв'язок з галуззю масової музичної культури, враховуючи і їі театральні відгалуження та віддзеркалення. Зокрема, з жанрово-стратифікаційної точки зору суттєвою є спорідненість з деякими формами мюзиклу та рок-опери, а взаємодія театрально-постановочної форми мюзиклу та індивідуальної (індивідуально-групової) форми концертного виступу - естрадного шоу набуває естетичної значущості, дозволяє визначати святковість та змістовну відкритість, загальнодоступність як провідні риси масово-музичного спілкування, а сугестію і компенсацію - як засадничі функціональні показники.

В деяких сучасних дослідженнях відзначається широкий вплив романтичної естетики на сучасний мистецький контекст, найбільше - в його популяризованих зрізах та вимірах. Підвищена експресивність, деяка фамільярність та і плакатність популяризованої музично-театральної форми досить цілісно відображена в мюзиклі та рок-опері, власне й утворює їх подібність у трактуванні подій та фактів, у вибудовуванні сюжетних колізій та постатей провідних персонажів. Водночас і театральні жанри, пов'язані з мовним простором масової, тобто первинно-ужиткової, музичної культури, ще не отримали цілісної систематизованої оцінки.

Мета роботи постає як визначення тих тенденцій жанрової стратифікації українського вокально-естрадного виконавства, що вказують на його власну системну художню організацію. Методологія дослідження зумовлена поєднанням гносеологічного мистецтвознавчого та текстологічного музикознавчого підходів на основі культурологічного дискурсу.

Аналіз досліджень і публікацій, які можуть бути залученими до створення теоретичного апарату вивчення жанрової природи естрадного співу, веде до виділення когнітивної лінгвістики, котра дозволяє використовувати особливий аналітичний підхід до мовних засобів, причому не лише вербальних, а й іншого речово-знакового походження. Важливість даного підходу зумовлена зверненням до процесів категоризації та концептуалізації, таким чином до процесів смислопокладання як вираження пізнавальної активності людини, звідси й до комунікативного призначення даної активності [1; 4]. 
В дисертації І. Ковальської когнітивний підхід дозволяє глибше розкривати соціокомунікативну природу оперети у іiі історичному єднанні з музичною комедією, визначається широке змістове поле останньої. Задля цього автор активно застосовує поняття категорії (категорізації) та концепту, зокрема, зауважує, що категорія скеровує до відокремлення, найменування та функціональної специфікації опорних структурних ланок комунікативного процесу, раціоналізує та робить пізнаваним процес художньо-оціночної творчості. Концепт орієнтує на якість розуміння, його глибину та плідність, скоріше об'єднує, ніж диференціює, прагне до єдності знаку та значення, думки та вислову [3].

За спостереженням В. Карасика, концепт - це «фрагмент життєвого досвіду людини»; повторюючись, він фіксується в пам'яті, у тому числі в художній, зумовлює єдність принципів композиційностилістичної організації тексту. Тому процеси, які відбуваються на рівні жанрового розподілу - типізації, можна пояснити на основі явища художньо-мовної категоризації, яке, у свою чергу, пов'язано 3 концептуальними аспектами художньої форми. При цьому багатовимірність концепту пояснюється складною будовою реального світу - «життєвого світу», буденної реальності, відносин людини 3 цією реальністю. «Виділення обмеженої кількості аспектів розгляду концепту, як і мовної особистості, як і будь-якого предмета наукового вивчення, - це штучна міра розчленування дійсності з метою іiі пізнання» $[2,49]$.

Художня мова виявляє особливу залежність між концептуальними установками (загальними і індивідуалізованими, колективними та авторськими) і засобами, рівнями категоризаціі. Чим ширше поле концептуалізації, чим більш усуспільнений ії змістовний обсяг, тим чіткіше виражені прагматичні жанрові границі - межі «мовних стилів», тим довша низка лексем, що представляють ці стилі. Дослідження В. Карасика дозволяє знаходити в концептуалізації свого роду сприйняття і організацію світу, при якому кожна природна мова відображає певний спосіб розуміння світу, отже, кажучи про концептуалізацію, ми звертаємося до проблеми мовної картини світу. В іії зміст входить семантичне поле, а одиницею концептуальної картини світу дослідники вважають «константи свідомості». Таким чином, смислова картина свідомості відбивається у мовній картині світу, яка може бути уловлена і відтворена різними шляхами, але специфікується саме в мистецтві. 
Виділяється також низка робіт, які дозволяють дослідницькі поглиблювати вивчення антитетичних відносно «серйозної» музики видів професійної музичної творчості, зростаючих у царині масово-популярної культури та зосереджених на так званих тривіальних проявах людської свідомості й поведінки [7-9]. Звернення до явища тривіальності та екстраполяція даного поняття до сфери естрадної творчості виявляє нові закономірності існування «Номо aestheticus» (Б. Соколов) як «людини почуттєвої», що формується в буденному часовому континуумі та є невід'ємною від його «психологічної конституції» [7].

Виклад основного матеріалу. В різних формах мистецтва рівні категорізації та концептуалізації, разом з ними - явища первинної жанрової мови та вторинного жанрово-стильового змісту співвідносяться по-різному. У вищих стильових мистецьких формах, у яких панує творча авторська воля, концептуалізація передує категоризації; в наближеній до первинного середовища жанровій свідомості, як в повсякденній, переважають відомі засоби категоризації; при формуванні уявлення про світ та виділення його у художній формі саме вони спрямовують хід концептуального мислення, визначають його канонічні складові.

Мовна картина світу, створювана в естрадно-пісенній творчості, укріплена професійними засадами естрадного вокалу, відповідає завданню ціннісної регламентації життєвого досвіду культури, потім окремої особистості. Вона покликана виступати єдиною тканиною для соціального усвідомлення якісних цензів внутрішнього психологічного світу людини, тобто сприяти узгодженню одного з іншим, гармонізації когнітивного процесу у пізнанні та самопізнанні закономірностей спільного людського буття, покращанню можливості відчувати себе та іншого, розуміти, про що свідчать дані почуття (співчуття).

Звідси родова природа естрадної вокальної музики пов'язана 3 явищем звичаєвої культурної свідомості, яка не відділюється остаточно від перебігу звичаєвого часу, але дещо здіймається над ним, дозволяє узагальнювати його координати та вектори, краще володіти ним. Для цього вона приймає, поряд з узагальненістю, пізнаваністю, повторюваністю змістових та композиційних ознак, нову театралізовано-ігрову умовність та фестивалізується, тобто оголошує найближчий життєво-буденний (або професійно-обов'язковий) контекст «місцем свята», тим самим хротопічно виокремлює його та налашто- 
вує на здійснення традиційних очікувань реципієнтів, у широкому представленні останніх.

Як відомо, інтонаційно-слухові установки музики програмуються «репертуаром музично-мовних жанрів», i, навпаки, жанрово-стилістичне поле музики, особливо в іiї масовій ужитковій сфері, визначається настановами слухацької свідомості як колективного феномена. Взаємодія типової жанрової експресії з колективно-індивідуальними формами художнього сприйняття визначає еволюційний шлях естрадно-вокальної культури, що постає вторинним творчим явищем, особливо в силу зростаючої академізації, водночас залишається в «діалозі згоди» 3 первинною жанровою експресією масової музичної мови.

Саме зростання професійної майстерності $є$ у галузі естрадновокальної творчості показом значущості ії індивідуально стильових показників, тобто підсилює особистісні аспекти як самої вокальної творчості, так і ії сприйняття та оцінювання.

Естрадно-вокальна творчість претендує на особливе місце в психологічному «світі життя» пересічної людини, завдяки здатності активізувати свідомість і розсувати особистісні «горизонти очікування». Вона розвивається як жанрова галузь, що допускає створення власної аксіології і міфології, адресованої сучасній дійсності, також передбачає запозичення-повторність, хоча і в певних межах, використовує високі етичні мотиви, драматичні сюжетні колізії, складні життєві проблеми, але розв'язує їх засобами «загальних місць» та апеляції до вже наявного досвіду сприйняття та оцінки, як в загальножиттєвому, так і в художньому значеннях.

Звичайно, естрадній творчості, особливо в їі синтетичних проявах, разом з видовищним рядом та постановочними сценічними ефектами, властиві і гра з художнім матеріалом, і порушення «комунікативних очікувань», що знаменує прагнення до новизни - евристичності.

Але корінна властивість естрадної вокальної творчості - пріоритет виконавської форми, що набуває нових синтетичних характеристик, охоплює всі параметри художньої дії та постає ії стрижневим началом. Тому естрадний вокаліст, який є музичним артистом-виконавцем особливого роду, не лише репрезентує специфічний конгломерат виразових засобів музичного мистецтва, а й демонструє майстерність у володінні об'ємним комплексом мистецьких якостей. 3 їх розвитком та поданням - в буквальному значенні останнього слова - пов'язані режисерські постановочні рішення естрадних концертних вистав. 
Останні повинні мати цілісний та завершений характер, тобто бути організованими як текстологічна єдність, включаючи мізансценічні розташування та рух учасників естрадних шоу, відповідні до задуму виконавців художньо-декоративне оформлення, костюми тощо.

Головним фактором єдності виступає постать головного виконавця - співака, навколо якої організується сукупність композиційносценічних траєкторій, тобто весь матеріал вистави з його хронотопічними ознаками та вимогами. Якщо вокаліст-виконавець знаходиться в епіцентрі естрадної дії, то стосовно його художньо-психологічного тезаурусу, тобто по відношенню до семантичних констант створюваного ним образу сучасної особистості, провідними виявляються музично-мовні засоби, конотативне коло музичної стилістики.

Особливості його формування зумовлені тим, що воно не передбачає індивідуалізації окремих структурно-смислових прийомів, навпаки, вишикується шляхом широкого інтонаційного жанровостилістичного узагальнення, відбирає ті типові засоби музичної виразовості, які входять до повсякденної музичної свідомості, тобто є носіями сучасної звичаєвої музичної неориторики. Предметно-знакова сторона образу (тобто його емблематичні проекції та символічний ареал) визначається типовою жанровою (первинно-жанровою) експресією як слуховою формою оцінки колективного комунікативного досвіду.

Звичайно, і в цьому випадку музичний образ є оригінальною стилістичною конкретизацією музичного змісту, тобто набуває якості вторинності - навіть за умови зниження рівня авторизації матеріалу, розчинення «голосу соліста» в загальному звучанні «голосів естради». Але серед критеріїв вибору стилістичної фігури як логіко-семантичного прототипу музичного образу визначальними залишаються легкість (полегшеність) та тривіальність як обов'язкові якості естрадної шлягерної практики. Також зазначимо, що «героєм» у царині вокально-естрадного дійства є такий персоніфікований образ, котрий має високий ступінь усуспільнення, несе в собі значиму соціальну ідею, формується на основі типової жанрово-мовної експресії.

У зв'язку зі сказаним, ще раз уточнимо, що категорія музичносценічної гри стосовно вокально-естрадного виконавства набуває нових параметрів, передбачає складний комплекс художніх здібностей і особистісно-артистичних якостей, останнім часом - і застосування нових технологічних сценічно-постановочних «контамінацій», що ще більше підсилюють синтетичну природу сценічної поведінки 
і самовираження естрадного співака, вказують на їі власні нові «академічні норми» (які повинні відображатися у формах освітньо-професійної підготовки).

Разом з тим зростає і суттєва відмінність (при певному зближенні академічного, «класичного», та естрадного, «акласичного», хоча й орієнтованого на типізовані взірці) видів вокального виконавства, тобто зберігається суттева професійна дистанція між формами вокального виконавства і типами артистів. Головне тут - специфіка володіння професійним музично-виконавським та загальним артистичним апаратом, тобто інший вид академізації порівняно 3 «елітарно-взірцевими» формами музичного мистецтва, починаючи зі способів звуковидобування у роботі з мікрофоном та завершуючи володінням спільними з іншими сценічними учасниками танцювальними рухами.

Найбільш помітними чинниками семантичної різниці між класичною та естрадною вокальними професійними системами є відбір та застосування словесно-мовних форм, у активній співдії з якими народжуються і музично-мовні прийоми. Можлива класифікаційна співвіднесеність словесно- та музично-мовних засобів естрадного вокалу, у свою чергу, обумовлена особливим місцем образу людини в створюваній даною жанровою сферою картині світу - людини і як умовного етичного суб'єкта, і як живої особистості, що обирає власну життєвотворчу позицію.

Як зазначається в сучасній когнітивістиці, існує певний поточний «мовний кодекс», що включає універсальні висловлювання і інші прецедентні тексти, як складові культурного контексту. Він повинен бути зрозумілим середньому носію мови, орієнтувати на правила поведінки, комунікативні стратегії, ціннісні позиції. Так само існують загальнолюдські цінності (як етичні, так і утилітарні); цінності, властиві певному типу цивілізації (наприклад, норми поведінки відповідно до того чи іншого віровчення); цінності, що характеризують певний етнос, а також підгрупи всередині етносу; нарешті, виділяються цінності, властиві малим групам та індивідуальні цінності особистості. Тому так звану «комунікативну особистість» можна знайти за співвідношенням домінантних цінностей та за ступенем їх диференціації $[2,26-100]$.

В. Карасик виділяє різні підходи до типології мовних особистостей, відзначаючи, що дана типологія може розроблятися з позицій соціокультурної лінгвістики - з виділенням типів мовних особистос- 
тей з об’єктивними статусними ознаками (вік, стать, рівень освіти, стиль життя і т. ін.); з узагальнено-соціологічних позицій, коли виділяються певні соціальні типи - героїв, лиходіїв, клоунів, жертв та ін.; з соціально-психологічних позицій, що відображено в хрестоматійно відомій функціональній типології персонажів чарівної казки, близькій до актантного моделювання. Відтак на підставах соціолігвістичного підходу може виникати і свого роду «мовний портрет» людини. В. Карасик особливу увагу приділяє поведінковим характеристикам мовної особистості, знаходячи в них сукупність вербальних і невербальних індексів, що визначають мовну особистість як індивідуума або як тип. Його словами, «в самому широкому плані, говорячи про людину в аспекті іiі комунікативної поведінки, ми маємо на увазі прагмалінгвістичні параметри мовної особистості, тобто розглядаємо спілкування як діяльність, що має мотиви, цілі, стратегії і способи їх реалізації» $[2,67]$.

Відтак персоналізація як властивість вокально-естрадного виконавства передбачає, перш за все, залучення певних мовно-особистісних ознак, за якими можуть розпізнаватися соціально статусні типи поведінки, психологічного реагування, емоційної самоідентифікації тощо. Причому у процесі концертного виступу вони представлені оновлено, в єдиній художньо-комунікативній стратегії, що дозволяє укрупнювати деякі з них, наприклад деталізовані прийоми словесномовленнєвої риторики або, навпаки, музично-інтонаційне піднесення та змістове узагальнення. В новій смисловій єдності естрадного вокального тексту соціальна статусність мовної поведінки змінюється на естетично-художню, тобто набуває іншого ціннісного виміру. Вона наповнюється новими якостями як тими особистісними значеннями, котрі виникають при наявності творчої свободи, підйому над буденністю, енергії позитивного співчуття.

Не менш важливим буде вказати на конститутивне значення аксіології гри в усіх аспектах естрадної вокально-артистичної діяльності, передусім у загальній часопросторовій організації сценічної дії, частиною якої постає вокальний мелодичний вислів - образний самовияв артиста.

Таким чином, наукова новизна роботи полягає у виявленні чотирьох провідних тенденцій розвитку вокально-естрадної жанрової системи, що надають їй художньо-творчої та культурно-семантичної автономії - театралізації, фестивалізації, академізації та персоналізації. 
Висновки. Вокально-естрадне виконавство в Україні є найбільш широкою та об'ємною за жанровими складовими сферою музичносценічної творчості, що має власну систему гносеологічних та аксіологічних ознак, виводить сучасне і актуальне на рівень універсальних категорій - скерована до ідеї всезагального глобалізованого соціуму, надаючи ціннісного темпорального виміру повсякденній свідомості, веде до нової академізації, тому базується на принципах професійної композиторської й виконавської творчості та здійснює стильові і стилістичні інновації. Підпорядковуючи ліричну, індивідуально-особистісну образну сферу, воно надає їй особливої художньо-ігрової та музично-мовної концептуалізації.

\section{СПИСОК ЛІТЕРАТУРИ}

1. Беляевская Е. О характере когнитивных оснований языковых категорий // Когнитивные аспекты языковой категоризации: сб. науч. тр. / отв. ред. Л. А. Манерко. Рязань: РГПУ им. С. А. Есенина, 2000. С. 9-14.

2. Ковальская И. Сюжетно-тематические основы и жанровые свойства музыкальной комедии (на примере репертуара Одесского академического театра музыкальной комедии имени М. Водяного): дис. ... канд. искусствоведения. Одесса, 2016. 201 с.

3. Карасик В. Языковой круг: личность, концепты, дискурс. Волгоград : Перемена, 2002. 477 с.

4. Михайлова Л. Категоризация как способ формирования концепта «говорение» в современном английском языке // Гуманитарные и социальные науки. Ростов на Дону, 2008. № 1. С. 86-90.

5. Окуджава Б. Жанр и время. Авторская песня: пути и перепутье // Советская музыка. 1988. № 9. С. 36-40.

6. Орджоникидзе Г. Звуковая среда современности // Музыкальный современник. М.: Советский композитор, 1983. Вып. 4. С. 272-304.

7. Соколов Б. Ното aestheticus: человек чувствующий vs человек эстетический // Онтологии чувственности. (Концептуализация Homo Aestheticus. Часть II). Санкт-Петербург: Издательство РХГА, 2015. С.13-30.

8. Шестаков Г. «Искусство тривиализации»: некоторые теоретические проблемы «массовой культуры» // Вопросы философии. 1982. № 10. С. 105116.

9. Якушенко И. Серьезно о легкой музыке: Обсуждаем проблемы массовых жанров / И. Якушенко // Советская музыка, 1972. № 4. С. 12-32. 


\section{REFERENCES}

1. Belyaevskaya, E. (2000). About the character of cognitive bases of language categories // Cognitive aspects of language categorization: coll. sci. tr. / ed. L. A. Manerko. Ryazan: RSPU them. S. A. Esenina, 9-14 [in Russian].

2. Kowalska, I. (2016). The subject-thematic bases and genre properties of musical comedy (on the example of the repertoire of the Odessa Academic Theater of the Musical Comedy named after M. Vodyaniy). Candidate's thesis. Odessa [in Russian].

3. Karasik, V. (2002). Language Circle: Personality, Concepts, Discourse. Volgograd: The Change [in Russian].

4. Mikhailova, L. (2008). Categorization as a way of forming the concept of «speaking» in modern English // Humanities and Social Sciences. Rostov on Don, N 1, 86-90 [in Russian].

5. Okudzhava, B. (1988). Genre and time. Author's song: ways and crossroads // Soviet music. № 9, 36-40 [in Russian].

6. Ordzhonikidze, G. (1983). Sound environment of our time // Musical contemporary. Moscow: Soviet composer, Issue. 4, 272-304 [in Russian].

7. Sokolov, B. (2015). Homo aestheticus: a person who feels vs aesthetic person // Ontology of sensuality. (Conceptualization of Homo Aestheticus, Part II). St. Petersburg: Publishing House of the Russian Academy of Civil Aviation, 13-30 [in Russian].

8. Shestakov, G. (1982).»The Art of Trivialization»: Some Theoretical Problems of «Mass Culture» // Issues of Philosophy. No. 10, 105-116 [in Russian].

9. Yakushenko, I. (1972). Seriously about light music: We discuss problems of mass genres / I. Yakushenko // Soviet music. № 4, 12-32 [in Russian].

Стаття надійщла до редакції 15.06.2016

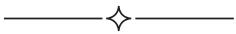

